УДК 581.14:58.035.3:633:34

DOI: $10.15587 / 2519-8025.2020 .201416$

\title{
INFLUENCE OF DIFFERENT PHOTOPERIODIC CONDITIONS ON THE PROTEIN AND OIL CONTENT IN SOYBEAN SEEDS (GLYCINE MAX (L.) MERR.)
}

\author{
Hayder Nabeel Hussein Al-Hamadeni, V. Zhmurko
}

\begin{abstract}
Мета. 3'ясувати вплив різної тривалості фотоперіоду на вміст білка і масла у насінні сортів сої, які різняться за реакиією на фотоперіод.

Матеріали та методи. У дослідах використані фотоперіодично нейтральні сорти сої Аннушка, Ятрань, Устя і короткоденний сорт Хаджибей. Рослини вирощували у польових умовах у 2016-2018 рр. на експериментальній ділянці кафедри фізіологї і біохімії рослин та мікроорганізмів Харківського національного університету імені В.Н. Каразіна на ділянках $1 \mathrm{M}^{2}$ у триразовій повторності. Від сходів до третього справжнього листка всі сорти росли за природного довгого дня (близько 16 год. на широті м. Харкова - 50 п.ш.). У ичю фазу протягом 14 днів для половини рослин створювали умови короткого фотоперіоду, затемнюючи рослини світлонепроникними кабінами з 17 до 9 години. Після чого рослини вирощували знову в умовах довгого природного дня до закінчення вегетачії. Друга частина рослин (контроль) протягом всього періоду вегетації була вирощена в умовах природного фотоперіоду. Вміст білка у насінні визначали на інфрачервоному аналізаторі Інфралюм ФТ-10 (виробник Люмекс, РФ), за методикою виробника, а масла - за Рушковським. Аналізи проведені у дво- триразовій повторності. У таблииях наведені середні та стандартні відхилення.
\end{abstract}

Результати. За умов короткого фотоперіоду вміст білка у насінні зростав, знижувався, або не змінювався, порівняно до вмісту на природному довгому дні, незалежно від характеру фотоперіодичної реакції досліджених сортів. Вміст масла у насінні рослин, які піддавали дії короткого фотоперіоду, був, як правило нижчим, ніж у насінні рослин, які вирощували за природного довгого дня. Вміст як білку, так $i$ масла варіював у різних сортів та в різні роки досліджень. Ступінь його варіювання у досліджуваних сортів різнився.

Висновки. Різні фотоперіодичні умови не однозначно впливають на вміст білка у насінні сортів сої з різною фотоперіодично реакиією, хоча в окремі роки у досліджених сортів проявляється тенденція до його зростання за умов короткого фотоперіоду. Вірогідно, він детермінується генотипом сорту та різними метеорологічними умовами періоду вегетації. Вміст олії у насінні досліджених сортів сої за впливу короткого дня знижується, порівняно до вмісту в умовах довгого дня, незалежно від фотоперіодичної реакиії сортів.

Зміни вмісту білка і масла в насінні сортів сої за різної тривалості дня не залежали від типу їх фотоперіодичної реакиії.

Вірогідно, щуо процеси накопичення білку $i$, особливо, олії у насінні сої контролюються тривалістю фотоперіоду, генетично детермінованого селекиійним відбором. Механізми такого контролю потребують подальшого поглибленого дослідження на рівні перебігу фізіолого-біохімічних процесів Ключові слова: соя (Glycine max (L.) Merr.), фотоперіод, темпи розвитку, білок, масло

Copyright (C) 2020, Hayder Nabeel Hussein Al-Hamadeni, V. Zhmurko. This is an open access article under the CC BY license (http://creativecommons.org/licenses/by/4.0).

\section{Introduction}

Soybean (Glycine $\max (\mathrm{L}$.$) Merr.) is one of the$ most valuable agricultural crops in the world for its diverse uses. First of all, this is determined by the biochemical composition of its grain. Its most valuable ingredients are protein and oil. The protein content in soybean grain reaches $40 \%$ or more. At the same time, soy protein is highly digestible by the human and animal organisms and contains almost all essential amino acids [1]. The oil content in soybean grain ranges from 18 to $20 \%$ and in some varieties reaches $28 \%$. In addition, soybean grain contains biologically active compounds, vitamins and minerals, which determine its high nutritional properties [1-3]. The described properties of soybean grain determine significant global cultivation areas
(125.4 million hectares) and large volumes of production (356.8 million tons). In Ukraine, soybean was sown in 2019 on 1.88 million hectares, and with a harvest of $2.58 \mathrm{t}$ / ha, its grain production amounted to 4.83 million tons [4]. One of the main conditions for expanding soybean crops in Ukraine and increasing yields is the creation of highly adaptive varieties to environmental factors. One of the factors that limit the spread of soybeans in growing areas and the formation of high grain yields with the high quality is the duration of the photoperiod, since soybean is a short-day crop by its biological nature $[2,5]$.

Therefore, the study of the influence of the duration of the photoperiod on the growth, development and yield of soybean seeds is important for the identification and use in the breeding process of the source material 
with a low photoperiodic sensitivity. We have shown that a change in photoperiodic conditions leads to a significant differentiation of soybean varieties and collection samples in response to the photoperiod, as well as a change in the nature of the manifestation of economically valuable traits [6]. Among the large set of studied varieties, those are selected that practically do not change the pace of development under different photoperiodic conditions, that is, they are photoperiodically neutral [5-7].

Despite the fact that the phenotypic manifestation of the reaction to the duration of the photoperiod in soybean varieties is fairly well studied [6], it has identified E genes [8], which determine the photoperiod sensitivity [9], and isogenic soy line genes [5], the effect of various photoperiodic conditions on the content of protein and oil in grain at this cost of culture has not been studied.

\section{Literature review}

Literature data on the influence of external conditions on the protein and oil content in soybean seeds are quite extensive. However, in most studies, as a rule, they studied the influence of either growing conditions or the genotype of the variety, as well as their interaction on these characters. So, when studying the content of protein and oil in the grain of 524 soybean samples for the period 1992-2014 year it was shown [10], that the protein content in the grain of the samples varies significantly depending on which ripeness group the samples belong to. The oil content in the grain, depending on the ripeness group of the samples, varied slightly. According to the author, in each ripeness group, samples were identified with both low and high protein and oil, as well as samples with a low level of variation of this trait. This suggests a dependence of the soybean grain quality level on the genotype of the variety.

Study [11] analyzed the dependence of the variability of protein and oil in the seeds of 1442 soybean samples in the conditions of the Krasnodar Territory of the Russian Federation, which were grown from 1987 to 2015 year due to changes in the temperature regime, as well as the moisture regime for this period. A tendency towards an increase in the protein content by $2.5 \%$ over 10 years has been identified, which is associated with an increase in the sum of effective temperatures and a slight decrease in the amount of precipitation. No reliable dependence of changes in the oil content on changes in temperature and precipitation has been established. The authors also showed that the oil and protein content is associated with the precocity of soybean samples. On average, the studied oil samples had the highest oil content and the lowest protein content in mid-ripening samples, while their content was relatively high in early ripe and late ripening samples.

In experiments with 68 soybean varieties during 2011-2013 year, there was investigated the dependence of the protein and oil content on the genotype of the variety and the maturation group, to which the variety belongs [12].

It was shown, that the protein content in the grain of the studied varieties varied in the range of $32.2-46.9 \%$. At the same time, there was a tendency to a decrease in the protein content in varieties of medium and late ripening (I-II ripening groups) compared with the content in varieties of ultra-early and early ripening groups (00-0 ripening group). The same authors showed that the fat content in the seeds of the varieties of the studied population varied from 18.7 to $24.0 \%$. At the same time, no reliable relationship was found between the fat content in seeds and the variety's belonging to a particular ripening group. Although the average ripening group is 0 and $\mathrm{I}$, its content was higher than that of varieties of other ripening groups. At the same time, among the varieties of all ripening groups, those were identified, whose protein and fat content in the seeds was maximum not only for this group, but for the entire studied population, which indicates the genotypic determination of these characters [12].

In experiments with six soybean genotypes, grown under different climatic conditions in years that differed in weather conditions, a significant effect of the genotype on the protein and oil content was shown. In addition, a high dependence of the level of protein in the grain on the level of tension of environmental factors temperature and humidity was fixed. No significant effect of environmental factors on the oil level in soybean was revealed [13].

When studying the dependence of the protein and oil content in soybean grain on the sowing dates and sowing rates in different vegetation periods according to weather conditions, it was shown, that the protein content in the grain is higher, the later the sowing period. The oil content, on the contrary, was higher in the early stages of sowing, compared to the content in the later stages. According to the authors, the leading environmental factors that affect the protein and oil content in soybean grain are temperature and precipitation level [14].

The content of protein and oil in the seeds of 763 samples of soybeans that were grown in 2010 2013 years in various regions of China was analyzed. The results showed that the protein content in soybean grain increased with increasing temperature depending on the growing region and weather conditions. According to the oil content in the grain, an opposite dependence was found on the weather conditions of cultivation [3]. When studying the oil and protein content in grain of 14 soybean varieties of ripeness groups 0 , I and II in conditions of Southeast Europe (Croatia), a significant dependence of the protein content on weather conditions during the years of research is shown. Weather conditions did not significantly affect the oil content [15]. Thus, the literature data show a significant dependence of the protein and oil content on the influence of environmental factors, primarily on temperature and level of moisture, as well as on the genotype of the variety. Dependence on these factors is more characteristic for the level of protein in soybean grain than for the level of oil content in it.

The most important environmental factors that significantly affect the growth, development and productivity of plants include the duration of the photoperiod. Some of the above works show the dependence of the protein and oil content on the growing region $[13,16]$. It is likely, that these regions could differ in the duration of the photoperiod, which, to one degree or another, could affect the protein and oil content in soybean seeds. However, the authors made no assumptions about this possible dependence. Never the less, the direct influence of 
the duration of the photoperiod on the protein and oil content in soybean is practically not studied. Only one work presents the results of such a study [17].

The authors studied the effect of an artificial short day (12 hours) on the protein and oil content in the seeds of two soybean varieties Lydia (early ripening) and Marinat (late ripening). It was shown, that under the influence of a short photoperiod, the protein content in the seeds of the Lydia cultivar did not change, while in the changes of the Marinata cultivar it decreased. The oil content under the conditions of a short photoperiod in the seeds of the Lydia variety was lower, and in the seeds of the Marinata variety, on the contrary, higher than under the conditions of the natural long photoperiod. The authors did not draw definite conclusions about the possible mechanisms that determine the accumulation of protein and oil in soybean seeds under different photoperiodic conditions. However, based on their data, it can be assumed, that the effect of the duration of the photoperiod on the level of protein and oil in the seeds of the studied varieties may be associated with the genotype of the variety.

\section{The purpose and objectives of research}

Based on the foregoing, the aim of this work was to study the effect of different photoperiodic conditions on the protein and oil content in the grain of soybean varieties with different photoperiodic sensitivity.

The research objectives included:

1. determine the content of oil and protein in the grain;

2. find out the possible relationship between the accumulation of protein and oil in soybean grain with the level of photoperiodic sensitivity of the studied varieties.

\section{Materials and Methods}

The plant material - four soybean varieties of Ukrainian selection - Annushka, Ustya, Yatran and Khadzhibey. According to the results of our previous studies [18], these varieties differ in photoperiodic sensitivity. Varieties Annushka, Ustia and Yatran under the influence of a short photoperiod did not change the timing of the transition to flowering. Therefore, they were assigned by us to the group of photoperiodically neutral plants. Under the conditions of a short photoperiod, the Khadzhibey variety earlier passed to flowering and ripening than under the conditions of a natural long day, which became the basis for classifying it as a group of short-day plants [18]. The seeds of these varieties for research are kindly provided by the National Center for Plant Genetic Resources of Ukraine - V. Ya. Yuriev NAASU. The experiments were conducted in the field conditions in 2016-2018 at the experimental site of the Department of Physiology and Biochemistry of Plants and Microorganisms of V. N. Karazin Kharkiv National University, which is located on the territory of the University Botanical Garden.

Seeds were sown at the optimum time - the I-II decade of May on plots of $1 \mathrm{~m}^{2}$ in triplicate each version of the experiment. Prior to the phase of the third true leaf, all varieties were grown under conditions of a natural long day (about 16 hours at the latitude of Kharkov $-50^{\circ} \mathrm{N}$ ). In this phase, one part of the plants of each cultivar was exposed to an artificial short day (9 hours), and the second was continued to grow on a natural long day. A short day was created by darkening the plants with opaque material from 17 to 9 hours. The exposure to a short photoperiod continued for 14 days, and then the plants were grown on a natural long day until the end of the growing season.

The protein content in the seeds was determined on an Infralum FT-10 infrared spectrometer (Lumex, RF, spectral range $880-1160 \mathrm{~nm}$ ) in accordance with the manufacturer's recommendations, and the oils by the gravimetric method according to Rushkovsky [19]. Analyzes were performed in triplicate.

The results were processed statistically [20]. The significance of the influence of a short photoperiod on the protein and oil content in soybean seeds was judged by the Student criterion $(\mathrm{t}-$ test at $\mathrm{P} \leq 0.05)$. The tables show mean values and standard deviations.

\section{Results and discussion}

The data obtained showed (Table 1) that, under natural day conditions, the protein content in the seeds of the studied varieties depended on the genotype of the variety, as well as on the conditions of the growing season in different years of research. So, in different years of research under natural photoperiodic conditions, the protein content in the seeds of the varieties Annushka, Yatran and Ustya was, as a rule, lower than in the seeds of the Khadzhibey variety. It is likely, that this depends on the ripeness group of varieties. According to our data [18], Annushka, Yatran and Ustya varieties had a shorter growing season than Khadzhibey cultivar under natural day conditions. It was shown [11], that in varieties of later maturity, the protein content was higher than in varieties of earlier maturity.

In the experiments of other authors [12], an inverse relationship was found between the protein content in soybean grain and the ripeness group of varieties. Although these published data are contradictory, it can be assumed, that the protein level in the grain of soybean varieties of different ripeness groups varies, as our data also indicate (Table 1). The analysis of the obtained data also showed that, regardless of the genotype of the variety and photoperiodic conditions, the protein content in the seeds of the studied soybean varieties in different years was different. This is evidenced by the results of determining the level of variation in the protein content (Table 1). Under natural day conditions in all varieties, the degree of variation in the protein content was higher than under short day conditions. This indicator varied differently in the studied varieties - in varieties Annushka and Ustya, the variance and coefficient of variation were higher than in varieties Annushka and Khadzhibey both under natural day and short day conditions (Table 1). The above suggests that the level of protein in the seeds of the studied varieties in a natural day depends on the genotype of the variety and the conditions of the growing season, as well as on the genotype-environment interaction. This assumption is confirmed by published data, which show the dependence of the protein content in the grain of many soybean varieties, grown in regions that differ in temperature and moisture conditions during their growing season $[3,16]$. 
Table 1

The influence of the duration of the photoperiod on the protein content in the seeds of soybean varieties with different photoperiodic reactions, $\%$

\begin{tabular}{|c|c|c|c|c|c|c|}
\hline \multirow{2}{*}{ Photoperiod } & \multicolumn{3}{|c|}{ Protein content in years, $\%$} & \multirow{2}{*}{$\begin{array}{c}\text { Average } \\
\bar{X}, \%\end{array}$} & \multicolumn{2}{|c|}{ Variation } \\
\hline & 2016 & 2017 & 2018 & & $\sigma, \%$ & $\mathrm{~V}, \%$ \\
\hline \multicolumn{7}{|c|}{ Annushka - photoperiodically neutral variety } \\
\hline 16 hours* & $31.4 \pm 0.1$ & $38.4 \pm 0.1$ & $32.5 \pm 0.5$ & 31.4 & 3.76 & 11.9 \\
\hline 9hours & $30.5 \pm 0.3$ & $36.9 \pm 0.2$ & $34.3 \pm 0.2$ & 33.9 & 3.22 & 9.4 \\
\hline \multicolumn{7}{|c|}{ Yatran - photoperiodically neutral variety } \\
\hline 16 hours & $31.4 \pm 0.2$ & $41.6 \pm 0.4$ & $37.4 \pm 0.2$ & 36.8 & 5.12 & 13.9 \\
\hline 9hours & $30.4 \pm 0.2$ & $35.6 \pm 0.5$ & $39.3 \pm 0.5$ & 35.1 & 4.47 & 12.7 \\
\hline \multicolumn{7}{|c|}{ Ustya - photoperiodically neutral variety } \\
\hline 16 hours & $29.5 \pm 0.2$ & $36.7 \pm 0.3$ & $39.7 \pm 0.4$ & 35.3 & 5.24 & 14.8 \\
\hline 9 hours & $30.5 \pm 0.3$ & $37.7 \pm 0.4$ & $37.2 \pm 0.3$ & 35.1 & 4.02 & 11.5 \\
\hline \multicolumn{7}{|c|}{ Khadzhibey - short day variety } \\
\hline 16 hours & $32.6 \pm 0.2$ & $40.4 \pm 0.3$ & $41.1 \pm 0.5$ & 38.0 & 4.72 & 12.4 \\
\hline 9hours & $33.4 \pm 0.2$ & $39.5 \pm 0.4$ & $40.0 \pm 0.3$ & 37.6 & 3.67 & 9.8 \\
\hline
\end{tabular}

Notes: $1-*)$ - the duration of a natural day; 2 -differences in the protein content under the conditions of the 16-hour and 9-hour photoperiods are not significant: the average difference between the options is $d=0.650$; error of the average difference $S d=0.641$; $t$ fact $0.05=1.01$; $t$ st $0.05=2.2$ for $n=12, v=11$

The results of an analysis of the study of the effect of a short photoperiod on the protein content in seeds of soybean varieties showed the following (Table 1). In the experiments of 2016 year on a short day, the protein content in the seeds of the varieties Annushka and Yatran was lower, and in the seeds of the varieties Ustya and Khadzhibey it was higher than under the conditions of a natural long day. In the experiments of 2017, this pattern for the varieties Annushka, Yatran and Ustya was preserved. At the same time, in the seeds of the Khadzhibey variety, the protein content on the short day was lower than on the long day this year. In the experiments of 2018 year, under the conditions of a short photoperiod, the seeds of the varieties Annushka and Yatran contained more protein, while the seeds of the varieties Ustya and Khadzhibey, on the contrary, were less than under the conditions of a natural long day (Table 1). On average for 2016-2018 years, the protein content in the seeds of the Annushka variety on a short day was large, in the seeds of the Yatran and Khadzhibey varieties - less, and in the variety Ustya - the same as in natural day conditions (Table 1). This suggests that the accumulation of protein in soybean seeds may be sub- ject to photoperiodic control, but, apparently, this control is modified by the genotype of the variety, as well as by the conditions of the growing season. This assumption is indirectly confirmed by the above literature data on the influence of environmental factors on the protein content in soybean seeds, since the duration of the photoperiod is one of the most important among those that determine the productivity and quality of plant crops [6].

The second most important component of soybean seeds is oil, the level of which is subject to the dependence on environmental factors, although to a lesser extent than the protein content $[3,11,16]$. It is possible, that the accumulation of oil may be subject to photoperiodic regulation. Therefore, we studied the effect of the duration of the photoperiod on the oil content in the seeds of soybean varieties with a contrast photoperiodic reaction.

The results obtained showed (Table 2) that under the conditions of a natural long day, the varieties studied differed in the total level of oil content in the seeds. So, in the Yatran and Ustya varieties its content during all the years of research, with rare exceptions, was greater than in the Annushka and Khadzhibey varieties.

Table 2

The influence of the duration of the photoperiod on the oil content in the seeds of soybean varieties with different photoperiodic sensitivity, $\%$

\begin{tabular}{|c|c|c|c|c|c|c|}
\hline \multirow[t]{2}{*}{ Photoperiod } & \multicolumn{3}{|c|}{ Oil content in years, $\%$} & \multirow{2}{*}{$\begin{array}{c}\text { Average }, \\
\bar{X}, \%\end{array}$} & \multicolumn{2}{|c|}{ Variation } \\
\hline & 2016 & 2017 & 2018 & & $6, \%$ & $\mathrm{~V}, \%$ \\
\hline \multicolumn{7}{|c|}{ Annushka - photoperiodically neutral variety } \\
\hline 16 hours $*$ & $19.4 \pm 0.2$ & $16.2 \pm 0.2$ & $14.6 \pm 0.1$ & 16.7 & 2.4 & 14.4 \\
\hline 9 hours & $19.2 \pm 0.5$ & $15.7 \pm 0.1$ & $15.0 \pm 0.2$ & 16.6 & 2.3 & 13.9 \\
\hline \multicolumn{7}{|c|}{ Yatran - photoperiodically neutral variety } \\
\hline 16 hours & $19.0 \pm 0.3$ & $19.0 \pm 0.4$ & $17.1 \pm 0.3$ & 18.4 & 1.1 & 6.0 \\
\hline 9 hours & $18.5 \pm 0.3$ & $16.9 \pm 0.3$ & $16.3 \pm 0.4$ & 17.2 & 1.3 & 7.6 \\
\hline \multicolumn{7}{|c|}{ Ustya - photoperiodically neutral variety } \\
\hline 16 hours & $19.5 \pm 0.3$ & $18.5 \pm 0.5$ & $19.4 \pm 0.4$ & 19.1 & 0.6 & 3.1 \\
\hline 9 hours & $19.5 \pm 0.1$ & $16.7 \pm 0.3$ & $17.9 \pm 0.2$ & 18.0 & 1.4 & 7.8 \\
\hline \multicolumn{7}{|c|}{ Khadzhibey - short day variety } \\
\hline 16 hours & $18.5 \pm 0.3$ & $16.2 \pm 0.2$ & $18.0 \pm 0.3$ & 17.6 & 1.2 & 6.8 \\
\hline 9 hours & $18.7 \pm 0.5$ & $16.0 \pm 0.1$ & $17.1 \pm 0.2$ & 17.3 & 1.4 & 8.1 \\
\hline
\end{tabular}

Notes: 1. *) - the duration of a natural day; 2 - differences in the oil content under the conditions of the 16-hour and 9-hour photoperiods are significant: the average difference between the options is $d=0.658$; the error of the average difference $S d=0,229 ; t$ fact $0.05=2.8$; $t$ st $0.05=2.2$ for $n=12, v=11$ 
Only in the experiments of 2016 year in the seeds of the variety Annushka the oil contained the same amount as in the varieties Yatran and Ustya (Table 2). In our opinion, this is due to the genotypic characteristics of the studied varieties for the accumulation of oil in seeds. Literary data also testify to the genotypic control of this process in soybeans.

The data obtained also showed that in different years of research, the oil content in the seeds of the studied varieties varied, regardless of the genotype of the variety and photoperiodic conditions. Although this variation was insignificant (Table 2), nevertheless, it indicates that the accumulation of oil in soybean seeds depends on the level of tension of environmental factors, which varied during the years of research.

Under the influence of a short photoperiod, the oil content in the seeds of the studied varieties, as a rule, significantly decreased in comparison with the content under the conditions of a natural long day (Table 2). Only in the experiments of 2016 year in the seeds of the varieties Ustya and Khadzhibey under the conditions of a short day the oil contained the same amount as on a natural long day. In the experiments of 2018 year, there was more oil in the seeds of the Annushka variety on the short day than on the long day (Table 2). Thus, a short photoperiod caused a decrease in the oil content in the seeds of the studied soybean varieties.

\section{The discussion of the results}

An analysis of the results showed that the protein and oil content in the seeds is subject to photoperiodic regulation. However, it necessarily changes the meteorological conditions during the growing years, as well as the genotype of the variety.

The fact that the protein content in the seeds of the researchers was different is probably due to the group of their ripeness. It was established [18], that the photoperiodically neutral varieties, used in our experiments, ripened under natural conditions earlier than the shortday variety. According to some literature data [11], the higher protein content was in the early stages of maturation, and according to others - in the late ripening stages [12]. The probability is that the protein content in the grain depends on the ripeness group.

According to the literature $[3,11,16]$, the content of protein and oil in soybean grain significantly depends on the level of temperature and moisture, as well as on the genotype-environment interaction. Since we conducted studies in different years with varieties, differing in maturity and the nature of the reaction to the photoperiod, it is likely, that in our experiments these effects on the level of protein and oil in soybean seeds were also manifested.

The comparison of the data, obtained by us, and the results of studies of other authors gives reason to believe that we supplemented the existing ideas about the dependence of the accumulation of protein and oil in soybean seeds on environmental factors in the sense that we isolated from the complex of environmental factors, acting on the plant, one of the most important - the influence of the duration of the photoperiod, which largely determines the spreading of plants by growing zones, growth, development, and productivity [6].

The literature data, presented in the article on the effect of the photoperiod on the protein and oil content in soybean seeds, are limited to one work [17], since we did not find such works in the literature, available to us. In this work, authors used two soybean varieties with an unknown photoperiodic reaction, which belong to different ripeness groups. Probably, the authors relied on the widespread notion that soybeans belong to short-day plants. However, as shown by us [6], among soybean varieties, many are photoperiodically neutral. These varieties are capable of producing sufficiently high grain yields in regions that vary in day length during the growing season of plants, which is important for promoting soybean culture, in particular, in the more northern regions of cultivation.

We have shown that under the influence of a short photoperiod in soybean seeds, the oil content decreases, although its level varied in different years of research and varied depending on the genotype of the variety. This coincides with the literature data that the oil level in the seeds of many soybean varieties is significantly less variable, depending on environmental factors than the protein level, but is more determined by the genotype of the variety $[3,11,16]$. It is likely, that the level of oil accumulation in soybean seeds is subject to photoperiodic regulation to a greater extent than protein accumulation.

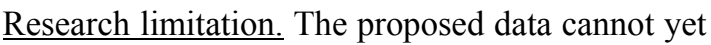
be used to create soybean varieties with a stable level of protein and oil in seeds for growing under different photoperiodic conditions. Probably, further it is necessary to identify the genetic control of these processes on the part of the EE series genes in soy, which determine its photoperiodic sensitivity.

Prospects for using research results. The results of the experiments can be used to evaluate the source material of soybeans in breeding programs for the creation of varieties with a high adaptive potential to environmental factors. The data obtained make a definite contribution to the theoretical aspects of plant photoperiodism and may be important for further deepening the existing ideas about the biological laws of the photoperiodic reaction of plants.

\section{Conclusions}

Thus, the obtained data showed that in the seeds of soybean varieties with different photoperiodic reactions under the influence of shortening the photoperiod, the protein content does not change regularly, although in some cases there was a tendency to increase it in some years of research under these conditions. At the same time, the oil content under the influence of a short photoperiod in almost all studied varieties is significantly reduced. This suggests that the accumulation of protein and oil may be subject to photoperiodic control. We have not revealed any regular differences in the content of protein and oil under different photoperiodic conditions in the seeds of soybean varieties, which differ in the nature of the photoperiodic reaction. 
The results also showed that the content of protein and oil, regardless of photoperiodic conditions, is subject to variation, depending on the genotype of the variety and on meteorological environmental conditions during the years of research.

In our opinion, for a deeper understanding of the patterns of protein and oil accumulation in soybean seeds, studies of the physiological and biochemical mechanisms of these processes are necessary.

This work was carried out as part of the scientific research topic "Study of molecular genetics and physiological biochemical mechanisms of vernalization and photoperiodic control of plant ontogenesis in vivo and in vitro", N state registration $0118 \mathrm{U} 002104$.

\section{Acknowledgements}

This work was carried out as part of the scientific research topic "Study of molecular genetics and physiological biochemical mechanisms of vernalization and photoperiodic control of plant ontogenesis in vivo and in vitro", N state registration $0118 \mathrm{U} 002104$

\section{Conflict of interest} interest.

The authors declare that they have no conflicts of

\section{References}

1. Petibskaia, V. S.; Lukomets, V. M. (Ed.) (2012). Soia: khimicheskii sostav i ispolzovanie. Maikop: OAO «Poligraf-IUG», 432.

2. Vishniakova, M. A., Seferova, I. V., Samsonova, M. G. (2017). Trebovanie k iskhodnomu materialu dlia selektsii soi v kontekste sovremennykh biotekhnologii. Selskokhoziaistvennaia biologiia, 52 (5), 906-916.

3. Song, W., Yang, R., Wu, T., Wu, C., Sun, S., Zhang, S. et. al. (2016). Analyzing the Effects of Climate Factors on Soybean Protein, Oil Contents, and Composition by Extensive and High-Density Sampling in China. Journal of Agricultural and Food Chemistry, 64 (20), 4121-4130. doi: http://doi.org/10.1021/acs.jafc.6b00008

4. United States Department of Agriculture, World Agricultural Production (2020). Circular Series February 2-20. USDA. Foraing Agr. Servise. Available at: https://apps.fas.usda.gov/psdonline/circulars/production.pdf

5. Zhmurko, V. V., Avksentieva, O. O., Yukhno, Yu. Yu., Popova, Yu. V., Samoilov, A. M. Tymoshenko, V. F. et. al. (2017). Efekty heniv fotoperiodychnoi chutlyvosti i potreby v yarovyzatsii u roslyn pshenytsi miakoi ta soi kulturnoi. Fiziolohiia roslyn: dosiahnennia ta novi napriamy rozvytku. Kyiv: Lohos, 187-197.

6. Zhmurko, V. V. (2009). Fizioloho-biokhimichni aspekty fotoperiodychnoho i yarovyzatsiinoho kontroliu rozvytku roslyn. Kyiv, 43.

7. Davydenko, O. H., Zhmurko, V. V., Holoienko, D. V., Rozentsveih, V. E., Shablinska, O. V. (2004). Proiav fotoperiodychnoi reaktsii u rannostyhlykh sortiv soi. Selektsiia i nasinnytstvo, 88, 151-162.

8. Jiang, B., Nan, H., Gao, Y., Tang, L., Yue, Y., Lu, S. et. al. (2014). Allelic Combinations of Soybean Maturity Loci E1, E2, E3 and E4 Result in Diversity of Maturity and Adaptation to Different Latitudes. PLoS ONE, 9 (8), e106042. doi: http://doi.org/10.1371/journal.pone.0106042

9. Xia, Z., Watanabe, S., Yamada, T., Tsubokura, Y., Nakashima, H., Zhai, H. et. al. (2012). Positional cloning and characterization reveal the molecular basis for soybean maturity locus E1 that regulates photoperiodic flowering. Proceedings of the National Academy of Sciences, 109 (32), E2155-E2164. doi: http://doi.org/10.1073/pnas.1117982109 $108,53-59$

10. Kobyzieva, L. N. (2015). Skryninh kolektsii soi NTsHRRU za vmistom v nasinni bilka ta zhyru. Selektsiia i nasinnytstvo,

11. Novikova, L. Y., Seferova, I. V., Nekrasov, A. Y., Perchuk, I. N., Shelenga, T. V., Samsonova, M. G., Vishnyakova, M. A. (2018). Impact of weather and climate on seed protein and oil content of soybean in the North Caucasus. Vavilov Journal of Genetics and Breeding, 22 (6), 708-715. doi: http://doi.org/10.18699/vj18.414

12. Abugaliyeva, A. I., Didorenko, S. V. (2016). Genetic diversity of soybean cultivars belonging to different ripeness groups with regard to performance and quality. Vavilov Journal of Genetics and Breeding, 20 (3), 303-310. doi: http://doi.org/10.18699/vj16.168

13. Ojo, D. K., Adebisi, M. A., Tijani, B. O. (2002). Influence of environment on protein and oil contents of soybeans seed (Glycine Max (L.) Merril). Global Journal of Agricultural Sciences, 1 (1), 27-32. doi: http://doi.org/10.4314/gjass.v1i1.2199

14. Bellaloui, N., Bruns, H. A., Abbas, H. K., Mengistu, A., Fisher, D. K., Reddy, K. N. (2015). Agricultural practices altered soybean seed protein, oil, fatty acids, sugars, and minerals in the Midsouth USA. Frontiers in Plant Science, 6 (31), 1-14. doi: http://doi.org/10.3389/fpls.2015.00031

15. Sudaric, A., Simic, D., Vrataric, M. (2006). Characterization of genotype by environment interactions in soybean breeding programmes of southeast Europe. Plant Breeding, 125 (2), 191-194. doi: http://doi.org/10.1111/j.1439-0523.2006.01185.x

16. Song, W., Yang, R., Yang, X., Sun, S., Mentreddy, S. R., Jiang, B. et. al. (2018). Spatial differences in soybean bioactive components across China and their influence by weather factors. The Crop Journal, 6 (6), 659-668. doi: http://doi.org/10.1016/j.cj.2018.05.001

17. Mysak, E. V., Selikhova, O. A. (2017). Izmenenie biokhimicheskogo sostava zerna soi v zavisimosti ot prodolzhitelnosti dnia. Prioritetnye napravleniia otraslevogo nauchnogo obespecheniia, tekhnologii proizvodstva, khraneniia i pererabotki selskokhoziaistvennoi produktsii. Krasnodar: FGBNU SKFNTSSVV, 245.

18. Zhmurko, V. V., Khaider, Nabil Khusein Al-Khamadeni (2018). Vliianie prodolzhitelnosti fotoperioda na formirovanie plodov u sortov soi (Glycine max (L.) Merr.). Faktori eksperimentalnoi evoliutsii organizmiv, 23, 57-63.

19. Ermakova, A. I. (Ed.) (1987). Metody biokhimicheskogo issledovaniia rastenii. Leningrad: Agropromizdat, 430.

20. Dospekhov, B. A. (1985). Metodika polevogo opyta (s osnovami statisticheskoi obrabotki rezultatov issledovanii). Moscow: Agropromizdat, 351.

Received date 14.01.2020

Accepted date 06.02.2020

Published date 28.02.2020

Hider Nabil Hussein Al-Hamadeni, Postgraduate Student, Department of Physiology and Biochemistry of Plants and Microorganisms, V. N. Karazin Kharkiv National University, Svobody sq., 4, Kharkiv, Ukraina, 61022

E-mail: agroch1984@hotmail.com

Zhmurko Vasily, Doctor of Biological Sciences, Professor, Department Physiology and Biochemistry of Plants and Microorganisms, V. N. Karazin Kharkiv National University, Svobody sq., 4, Kharkiv, Ukraina, 61022

E-mail: zhmurko@karazin.ua 